\title{
Antagonism between lead and zinc ions in plants
}

\author{
Renata Musielińska ${ }^{1 *}$, Jolanta Kowol ${ }^{2}$, Jerzy Kwapuliński ${ }^{3}$, Robert Rochel ${ }^{2}$ \\ ${ }^{1}$ Jan Dlugosz University, Poland \\ Department of Biology and Environmental Protection \\ ${ }^{2}$ Silesian University of Medicine, Poland \\ Department of Toxicology \\ ${ }^{3}$ Institute of Occupational Medicine and Environmental Health, Poland \\ ${ }^{*}$ Corresponding author's e-mail: r.musielinska@ajd.czest.pl
}

Keywords: lead, zinc, antagonism, plants.

\begin{abstract}
The article presents the results of research which describes antagonism between $\mathrm{Pb}-\mathrm{Zn}$ in selected plant species from the area of Czestochowa - Mirow district (north-western part of the Czestochowa Upland). There were analyzed changes in the ratio of $\mathrm{Pb} / \mathrm{Zn}$ in different organs of the tested plants as a function of the $\mathrm{Zn}$ content changes. The content of metals in the plants and the soil was determined using atomic absorption spectrophotometry AAS. In all organs of the plants there was observed antagonistic decrease of Pb uptake and accumulation, resulting from the increase in the concentration $\mathrm{Zn}$.

Antagonism between $\mathrm{Zn}$ and $\mathrm{Pb}$ in roots of the tested plants occurred at $\mathrm{Zn}$ content of 200-600 $\mu \mathrm{g} / \mathrm{g}$. In turn, antagonism in stems and flowers occurred at lower contents of zinc $(100-180 \mu \mathrm{g} / \mathrm{g})$. In leaves, antagonism between $\mathrm{Pb}$ and $\mathrm{Zn}$ occurred when $\mathrm{Zn}$ was present at the level of 300-800 $\mu \mathrm{g} / \mathrm{g}$.

Ex definition of the analyses confirm the presence of antagonism of lead with regard to high levels of $\mathrm{Zn}$. The study also confirmed that the degree of antagonism depends on the plant species.
\end{abstract}

\section{Introduction}

In recent times, plants contamination with various metal compounds related to the effects of human activity has been observed (Sas-Nowosielska 2009, Ociepa et al. 2008, Hławiczka 2008, Bednarek et al. 2005). Heavy metals of industrial pollutions prevent the full development of flora growing on spoil tips or the areas. The sources of plant pollution with heavy metals are also landfills, non-ferrous metal smelters, mines, plant protection chemicals, pesticides and fertilizers. The plants growing on the periphery of urban centers and busy roads contain $30-300 \mu \mathrm{g} / \mathrm{g}$ of $\mathrm{Pb}$, and even $>1000 \mu \mathrm{g} / \mathrm{g}$ of $\mathrm{Pb}$, wherein the average content of this element in the plant is in the range from 0.01 to $2.0 \mu \mathrm{g} / \mathrm{g}$ of $\mathrm{Pb}$ (Nagajyoti et al. 2010, Jadia and Fulekar 2009).

Ions of heavy metals may be a potential source of danger for the human and animals (Karczewska et al. 2008, Gruca-Królikowska and Wacławek 2006). Children and the elderly are particularly vulnerable to the toxic effects of heavy metals (especially cadmium and lead). Therefore there is an urgent need to minimize the negative effects of heavy metals on living organisms (Ociepa-Kubicka and Ociepa 2012, Kwiatkowska-Malina and Maciejewska 2011, Krzywy et al. 2010, Suna et al. 2010, Kabata-Pendias and Mukherjee 2007).

The uptake of toxic elements from contaminated soils by plants often exceeds their acceptable norms and leads to phytotoxicity (Niesiobędzka et al. 2005). The distribution of trace metal ions generally can be arranged as follows: roots
$>$ stems $>$ leaves $>$ fruit $>$ seeds (Jin et al. 2005). The uptake of metal ions by the plants depends not only on the content of the compounds of these elements in the soil, but also on the affinity of the plant in relation to the metal (Krzesłowska et al. 2010, Peralta-Videa et al. 2009, Vaillant et al. 2005, Lehmann and Rebele 2004).

In the mineral nutrition in plants there is often an antagonism between ions. The most significant antagonism exists between mono- and divalent cations, but it also occurs among cations of the same valency and anions. Each metal ion has a specific, characteristic manner of uptake, transport and accumulation in the plant, but in the presence of other ions in the soil there are also noted interactions between the ions (Eapen and D'souza 2005). These interactions can be of a neutral nature, wherein the occurrence of one element does not affect the uptake of others from the soil, or a synergistic one wherein there is observed an increase of one ion uptake in the presence of another and an antagonistic one - which is about stopping or reducing the uptake of one metal in the presence of another (Musielińska et al. 2014, Rout and Das 2003). As an example of the latter type of the interactions can serve antagonistic decrease in the uptake and accumulation of heavy metals in plants, e.g. ions of $\mathrm{Pb}$ or $\mathrm{Cd}$ with the increase of the concentration of trace elements in the soil, e.g. Zn (Aslan et al. 2003, Bolan et al. 2003, Sady 2001).

Concentration of heavy metals in soils, occurring especially in an easily bioavailable form to plants, may be the cause of an excessive uptake and negative influence on 
plants (Siwek 2008, Terelak et al. 2000). Under the influence of lead and other heavy metals inhibition of growth and delay of germination processes were observed (Furmanek and Andrzejewska-Ponomarev 2006, Rao 2006, Usman et al. 2006). The simultaneous occurrence of both lead ions as well as other metal ions (e.g., zinc) during their accumulation in different organs of the plant may lead to the antagonism of lead. Zinc plays an important role in plant metabolism. Both the deficiency or excess of the metal limit the growth and development of plants. Zinc is taken by the plant proportionally to its content in the soil, although both soil properties and the choice of the species have a significant influence on its content in plants. Therefore, it seems important to base the discussion of the phytoaccumulation abilities of different plant species on metal speciation analysis and on determining the way of the co-occurrence of selected elements (Krzesłowska et al. 2010, Gruca-Królikowska and Wacławek 2006).

In this light, the research which is not only to confirm the occurrence of antagonism between the selected metal ions in plants with similar contents of bioavailable forms of these metals in the soil, but also to answer the question of whether a potential antagonism between lead and zinc ions depends on the plant species seems to be justifiable.

\section{Materials and methods}

The study was conducted in the area of Czestochowa - Mirow district (240 $\pm 5 \mathrm{~m}$ a. s. 1. N 5049'20.05" E 19¹3'00.20"; N $\left.50^{\circ} 49^{\prime} 20.47^{\prime \prime} \mathrm{E} 19^{\circ} 13 ' 18.34^{\prime \prime} \pm 0.50 "\right)$. This area is a part of the Jurassic Landscape Parks and is directly adjacent to the "Gąszczyk" - the planned Wladyslaw Hyla forest reserve. It is located in the north-western part of the Czestochowa Upland (Poland) (Hereźniak 1984).

Plants were collected in the flowering period (60 species of 15 pieces) from 14 stands, each of an area of $5 \mathrm{~m}^{2}$. The plants washed with redistilled water and air dried in well ventilated, dry and clean rooms were crushed in an agate mortar, and ground using various types of mills, with special plastic blades. Samples of mass $1 \mathrm{~g} \pm 0.00001$ quantitatively transferred to conical flasks were treated with $10 \mathrm{~cm}^{3}$ of spectrally pure concentrated $(65 \%) \mathrm{HNO}_{3}$ Supra Pure Merck (Germany). The plant samples were digested in conical flasks of $100 \mathrm{~cm}^{3}$ sand bath at a temperature of $70^{\circ} \mathrm{C} \pm 2{ }^{\circ} \mathrm{C}$ until the clear solution.

Soil samples were taken after the thaw from the root layer of the tested plant habitats, from the surface without undergrowth of size $20-50 \mathrm{~cm}^{2}$. The soil, (each sample of $1.5 \mathrm{~kg}$ ) was dried using radiant tubes and ground in a mortar and sieved through a $1 \mathrm{~mm}$ mesh. In the next step the samples were ashed in a muffle furnace (temperature $400-600^{\circ} \mathrm{C}$ ) until the constant weight. Next, the soil samples (1 g each) were treated with spectrally pure concentrated $(65 \%) \mathrm{HNO}_{3}$ Supra Pure Merck (Germany) in an amount of $5 \mathrm{~cm}^{3}$. In order to isolate the various chemical forms of metal occurrence in the soil the samples were subjected to speciation analysis. The methodology of Rudd (Rudd et al. 1988), was applied, which is based on sequential extraction. Extractions of each of the samples (sample weight of the soil $1 \mathrm{~g} \pm 0,00001$ ) were carried out using a spectrally pure reagents in a ratio of 1:40: removable form - 1,0 $\mathrm{M} \mathrm{KNO}_{3}$; adsorbed form - $0.5 \mathrm{M} \mathrm{KF}$, $(\mathrm{pH}=6.5)$; organic connections $-0.1 \mathrm{M} \mathrm{Na}_{4} \mathrm{P}_{2} \mathrm{O}_{7}$; carbonates
- 0.1 M EDTA ( $\mathrm{pH}=6.5$ ); sulphides - 6.0 $\mathrm{M} \mathrm{HNO}_{3}$. The tested soil samples were treated with the mentioned above solutions within 24 hours. The next step was centrifugation (for 10 minutes) of the analyzed samples (400 rev./min), and then the samples were washed with redistilled water $(25 \mathrm{ml})$ and subjected to the centrifugation once more (for $5 \mathrm{~min}$ - $400 \mathrm{rev} / \mathrm{min})$. The obtained extracts were acidified to a concentration of $1 \% \mathrm{HNO}_{3}$. The recovery procedure ensured $\mathrm{Pb}$ and $\mathrm{Zn}$ in $99 \%$. Each series of measurements was conducted with three blind tests, the values of which were taken into account in the results of the tested samples. The heavy metal content in the tested samples of soils and plants was determined by atomic absorption spectrophotometry using a Spectrophotometer Pye Unicam SP9 with the use of a hollow cathode lamp and acetylene-air flame, to the nearest $0.01 \mu \mathrm{g} / \mathrm{g}$ (Whiteside and Milner 1984). The detection of the studied metals was $\left[\mu \mathrm{g} / \mathrm{cm}^{3}\right]: \mathrm{Pb}-0.100 ; \mathrm{Zn}-0,010$.

The precision and accuracy of assays was monitored with the standard addition method by National Metrology Institute as well as with a certified reference material of a comparable content of the tested metal in relation to the analysed material: for soils-CRM277 (BCR); for plants-CTA-VTL-2 (ICH and TJ). The differences were $2-4 \%$.

In addition, an intercalibration study (6 reference samples of the tested soil) was conducted in the Department of Environmental Monitoring, Central Mining Institute in Katowice. The results of analyses in comparison with the results of intercalibration study differ in the range of 3-5\%.

In the case of some plant species there was no material representing a specific organ. Such cases are indicated in Table 2 and in Figs. 1-4 with the mark (*), while in Figs. 5-8 there is included a number of samples, giving the value of $n$ for each organ of the tested plants.

\section{Results and discussion}

The content of lead and zinc $[\mu \mathrm{g} / \mathrm{g}]$ in soil samples and the percentage of metal in different chemical forms are shown in Table 1. Based on the obtained results of the lead and zinc content in the soil, one can rank these metals as follows: $\mathrm{Zn}>$ $\mathrm{Pb}$. Analysis of the results showed that the total lead content does not reflect the mobility and thus availability for plants. In the case of zinc one can indicate an inverse relation. The participation of zinc in two most mobile forms, exchangeable and adsorbed ones, shows a considerable availability for plants. According to the literature (Terelak et al. 2000), lead, due to the relatively limited solubility of minerals, is less mobile than zinc in the environment.

In the studied soils, there were small differences in the amount of lead (the standard error was $0.1 \mu \mathrm{g} / \mathrm{g}$ for $\mathrm{n}=14$ ). The total content of it in the soil was $23.5 \mu \mathrm{g} / \mathrm{g}$ which was similar to the results obtained in the soils of the north-eastern Poland - $29 \mu \mathrm{g} / \mathrm{g}$ (Niesiobędzka 2000). The average content of lead in agricultural land in Poland is $14 \mu \mathrm{g} / \mathrm{g}$ (Kabata-Pendias and Pendias 2001-a), in the Kłodzko Valley - $10 \mu \mathrm{g} / \mathrm{g}$ (Wacławek and Maćko 2001). According to Czarnowska (Czarnowska 1996) "geochemical background" the content this metal is 3 to $18 \mu \mathrm{g} / \mathrm{g}$ soil. Terelak and co-authors (Terelak et al. 2000) indicate that the average lead content in soils of agricultural land in Poland is $13.8 \mu \mathrm{g} / \mathrm{g}$. The level of lead in the tested soil did not exceed the limit value of $100 \mu \mathrm{g} / \mathrm{g}$ (Dz. U. No. 
165/2002 item. 1359). IUNG (Sauve et al. 1997) assumes as a natural value of lead concentration: about $31 \mathrm{mg} / \mathrm{kg}$ of $\mathrm{Pb}$ in light acid soils, $50 \mathrm{mg} / \mathrm{kg}$ of $\mathrm{Pb}$ in light neutral soils, and $70 \mathrm{mg} / \mathrm{kg}$ in heavy soils with a pH slightly acidic or neutral. The results obtained allow to classify the tested soils as "clean" ones with natural content of this component.

Zinc content in soil is typically in the range of 10-200 $\mu \mathrm{g} / \mathrm{g}$ (Dziubanek et al. 2012). In the tested soil the zinc content was at the level of $89.39 \mu \mathrm{g} / \mathrm{g}$, and the result is within the accepted limits, but it exceeds the content suggested by other authors. Kabata-Pendias (Kabata-Pendias and Pendias 2001-a) provides the limit of $\mathrm{Zn}$ content of $80 \mu \mathrm{g} / \mathrm{g}$ and Terelak and co-authors (Terelak et al. 2000) believe that the content of zinc in soils in Poland does not exceed $40 \mu \mathrm{g} / \mathrm{g}$. The literature data indicate that in the areas of urban and industrial emissions the zinc content in soils can exceed the normative values of $300 \mu \mathrm{g} / \mathrm{g}$ (Dziubanek et al. 2012), but in this case it does not. A comparison of the identified zinc content with the cited data (Niesiobędzka 2000) showed that the tested soils contain this element in geochemically average amounts.

Coexistence of $\mathrm{Pb}$ with $\mathrm{Zn}$ is described by the correlation coefficient: the positive one indicates directly proportional changes, and the negative one - changes which are inversely proportional. The interdependence of lead and zinc is described by the correlation coefficient, which in the exchangeable form in soil is 0.87 and in the absorbed form it is 0.38 . In the both cases the positive coefficient indicates directly proportional relation. According to Zwonitzer and co-authors (Zwonitzer et al. 2003), zinc usually accompanies lead in the soil, which is reflected in the obtained results.

The contents of lead and zinc in different organs of the studied plant species are shown in Table 2 .

The content of heavy metals in plants is generally a reflection of the amount of these bioavailable forms in soil. The results regarding the occurrence of heavy metals in plants are a valuable complement to the existing knowledge about the accumulation of metals in plants. In the analyzed plant species the lead content was in the range $[\mu \mathrm{g} / \mathrm{g}]: 2.49-33,80$ for roots; 2.49-8.32 for the stems; 2.48-5.26 for flowers; $2.49-13.65$ for leaves. The zinc content in different organs of the plant was $[\mu \mathrm{g} / \mathrm{g}$ ]: root: 20.79-531.31; stem: 9.03-171.92; flower: 20.09-170.68; leaf: 16.51-754.94. One must note that the level of $\mathrm{Pb}$ and $\mathrm{Zn}$ in some species exceeded the amount of these metals reported by other authors, e.g. in the species collected from southern Poland (Laszewska et al. 2007). According to the literature, the average lead content in plants from contaminated areas is even up to $387 \mu \mathrm{g} / \mathrm{g}$ (Wybieralski and Maciejewska 2011), while from uncontaminated areas it is about $0.4 \mu \mathrm{g} / \mathrm{g}$ (Niesiobędzka 2000) and $0.35 \mu \mathrm{g} / \mathrm{g}$ (Wacławek and Maćko 2001). In grasses studied on permanent pastures near Warsaw (Wawkonowicz et al. 2011), lead content was in the range of 3.9 to $7.5 \mu \mathrm{g} / \mathrm{g}$. These results do not indicate significant pollution of the species with the studied metal, however, they exceed the levels obtained by other cited authors. Wawkonowicz and co-authors (Wawkonowicz et al. 2011) indicate that in grasses the zinc content $(\mathrm{Zn})$ ranged between 16 and $48 \mu \mathrm{g} / \mathrm{g}$. However, according to Kabata-Pendias and co-author (Kabata-Pendias and Pendias 2001-a) the content of $\mathrm{Zn}$ in grasses in Poland is in the range from 12 to $72 \mu \mathrm{g} / \mathrm{g}$, with an average of $30 \mu \mathrm{g} / \mathrm{g}$. The results indicate that in the case of some plant species (Table 2) these values were significantly exceeded. The largest amounts of the metals were accumulated in the roots and leaves of the plants.

Lead is unevenly accumulated by the plant. Its concentration is greatest in those organs of the plants which are exposed to direct contact with its compounds. It is mainly accumulated (93-96\%) in the roots of plants (Badora and Kozłowska-Strawska 2011, Siwek, 2008, Gruca-Królikowska and Wacławek 2006). Only a small part of the quantities drawn gets into the shoots. The uptake of the metal ions by the roots is a passive process and depends on the levels of bioavailable forms in soil (Janowska and Szymańska 2005). The high levels of lead content in leaves of some plant species may indicate that the lead compounds from the atmosphere went into leaves through the stomata, or after a prior cuticle damage, for example, as a result of acid rain or ozone. This problem does not apply to high zinc content in the leaves of some species, because the cuticle and the hair layer are not a barrier for it (Skołożdrzy et al. 2001, Terelak et al. 2000, Woźny 1995).

Incidentally high levels of these elements were also in flowers and stems of some species. This fact may suggest the contamination of the plants with these metals, as a result of atmospheric dust fall (Kabata-Pendias and Pendias 2001-a). In the case of zinc it can be a natural process comparable to ions metal accumulation in roots and shoots (Siwek 2008).

Table 1. Concentration of lead and zinc $[\mu \mathrm{g} / \mathrm{g}]$ in soil samples and the percentage of the individual chemical forms in the soil

\begin{tabular}{|c|c|c|c|c|c|c|c|}
\hline \multicolumn{8}{|c|}{ Concentration of lead and zinc in the individual chemicals forms in the soil (the standard error $0,1 \mu \mathrm{g} / \mathrm{g} ; \mathrm{n}=14$ ) } \\
\hline Metal & $\begin{array}{c}\text { Total } \\
\text { content }\end{array}$ & $\begin{array}{l}\text { Removable } \\
\text { form }\end{array}$ & Absorbed form & $\begin{array}{c}\text { Organic } \\
\text { connections }\end{array}$ & Carbonates & Sulphides & Residual \\
\hline Zn & 89.39 & 2.49 & 54.43 & 11.03 & 10.42 & 4.05 & 6.96 \\
\hline $\mathrm{Pb}$ & 23.5 & 1.79 & 5.32 & 4.76 & 7.30 & 1.76 & 2.57 \\
\hline \multicolumn{8}{|c|}{ Percentage \% } \\
\hline \multicolumn{2}{|c|}{ Metal } & $\begin{array}{l}\text { Removable } \\
\text { form }\end{array}$ & Absorbed form & $\begin{array}{c}\text { Organic } \\
\text { connections }\end{array}$ & Carbonates & Sulphides & Residual \\
\hline \multicolumn{2}{|c|}{$\mathrm{Zn}$} & 2.79 & 60.89 & 12.34 & 11.66 & 4.53 & 7.79 \\
\hline \multicolumn{2}{|c|}{$\mathrm{Pb}$} & 7.62 & 22.64 & 20.25 & 31.06 & 7.49 & 10.94 \\
\hline
\end{tabular}




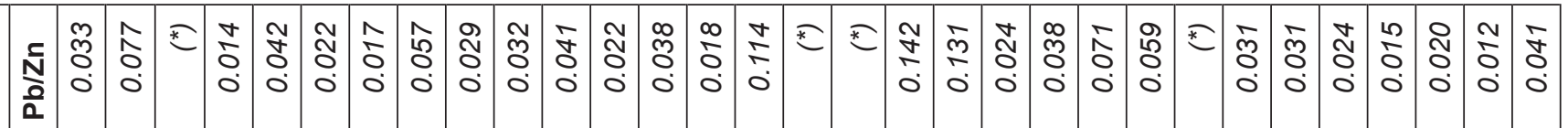

㟆

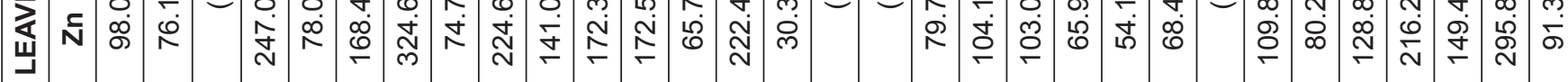

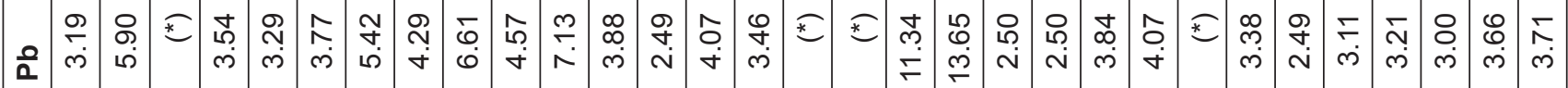

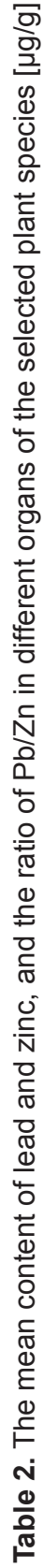

ร

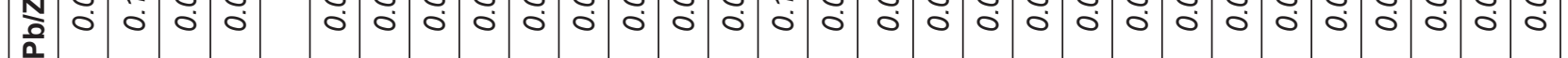

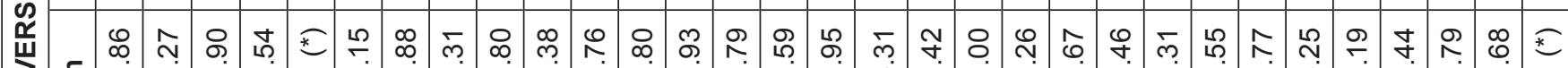

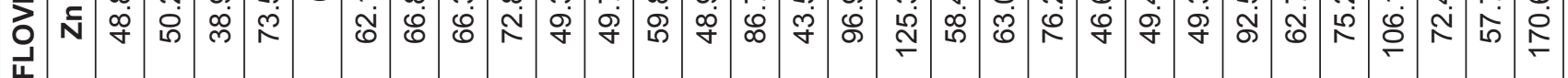

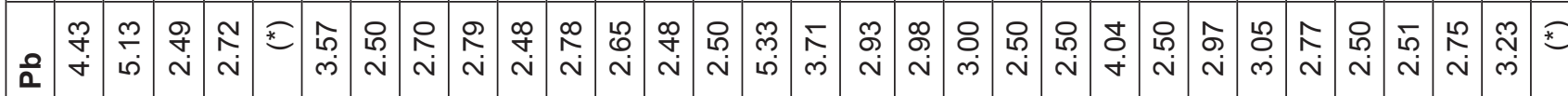

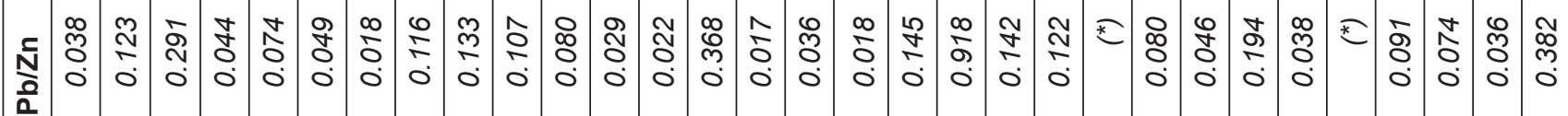

๓

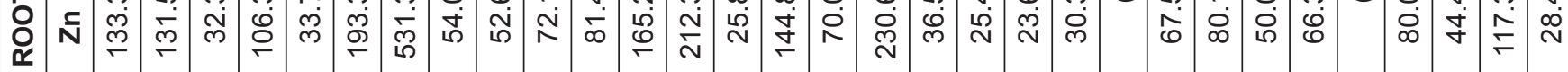

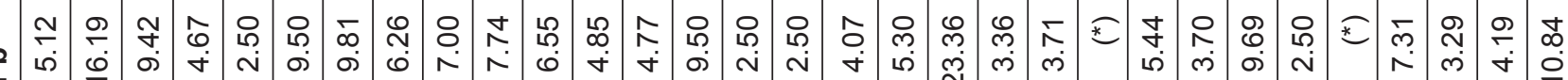

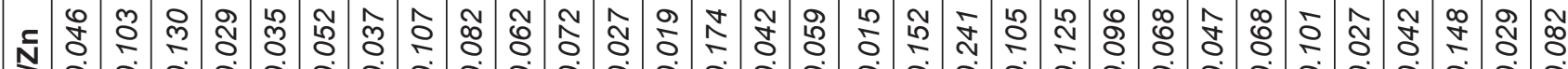
$\frac{2}{2}$

舟 芯

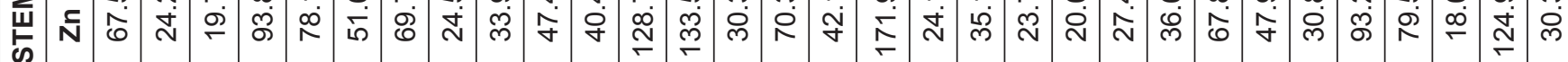

○ 舟

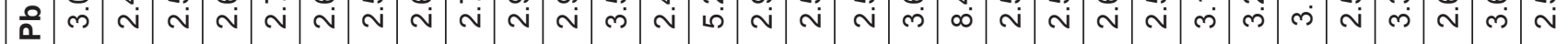

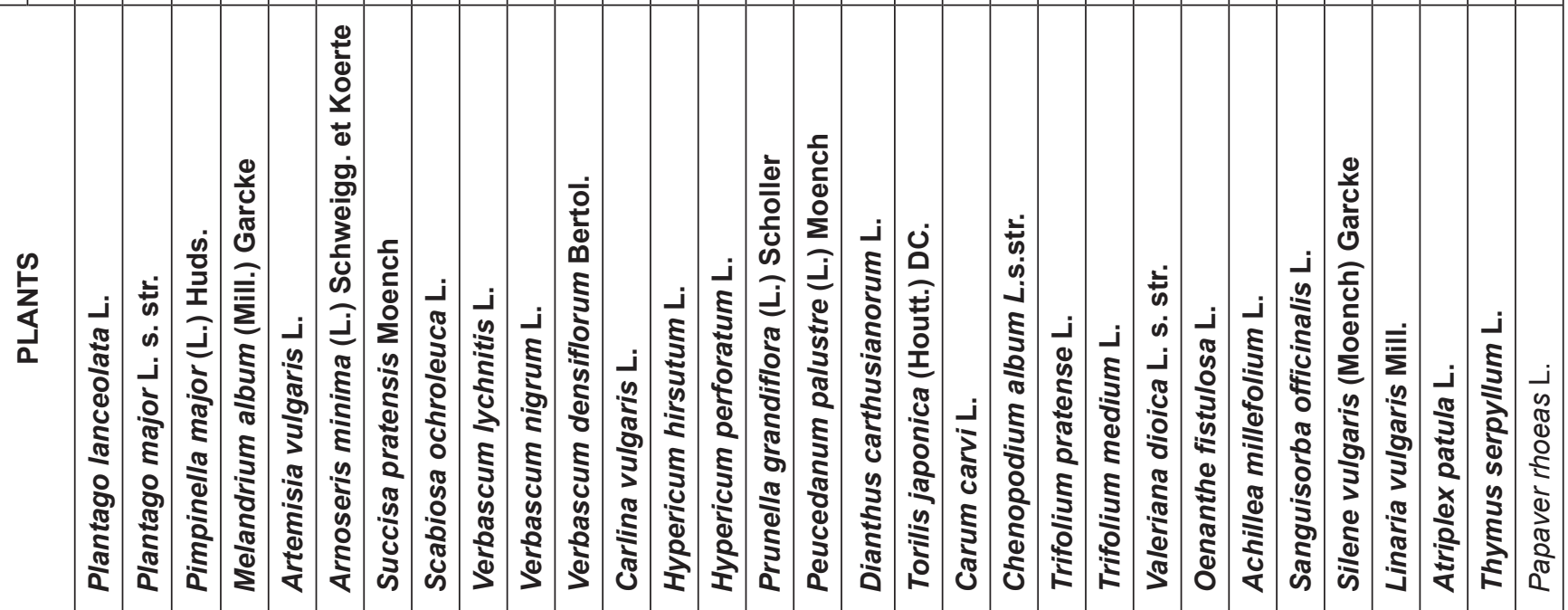




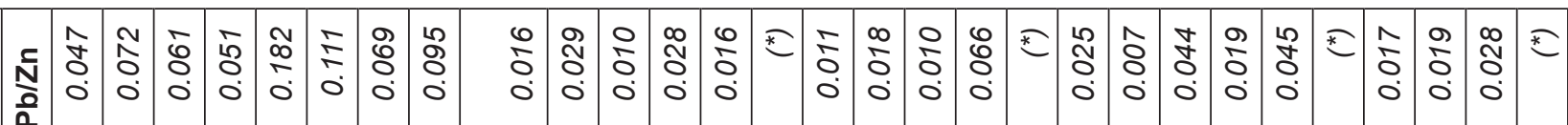

虫

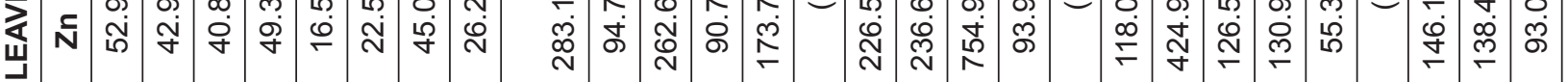

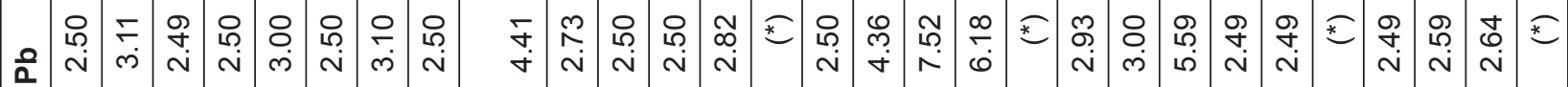

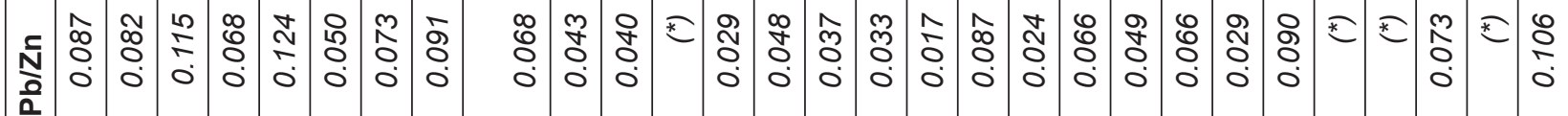

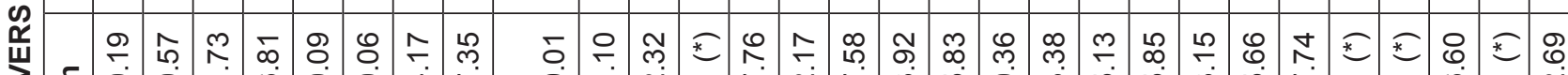

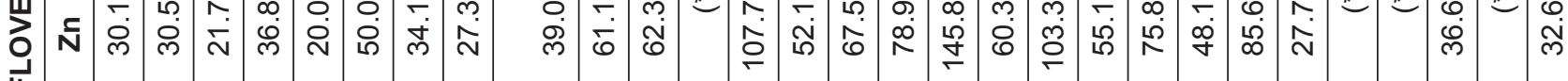
는

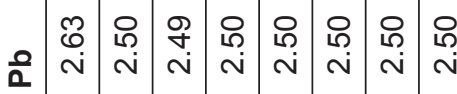

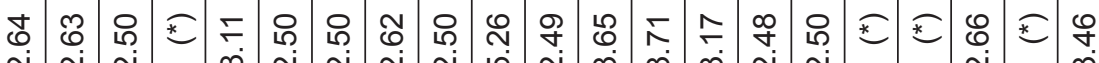

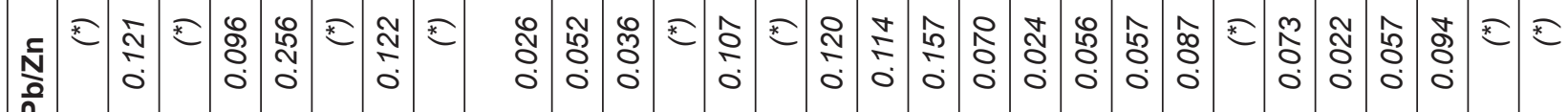

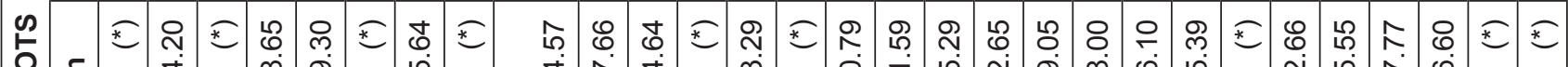

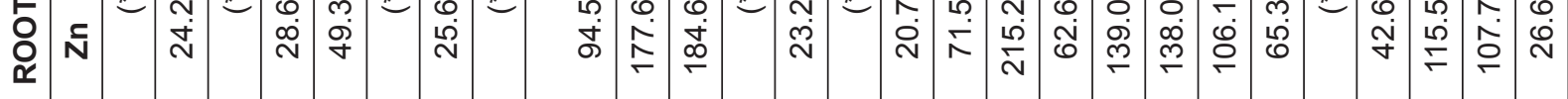

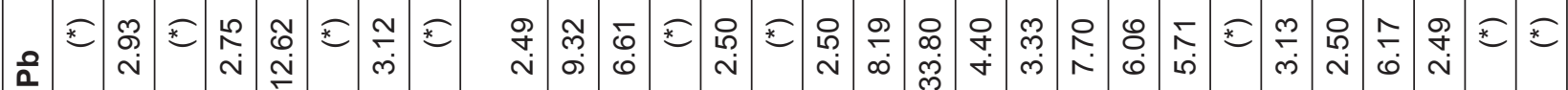

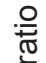

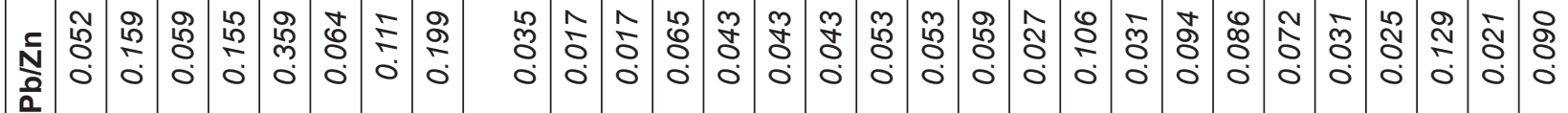

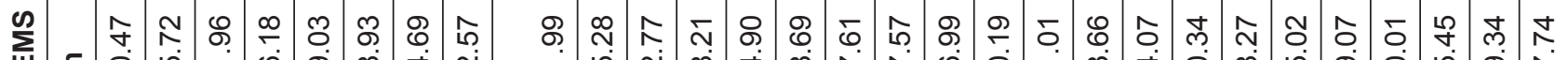
峁少

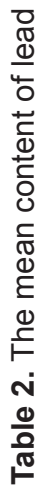
đํ.

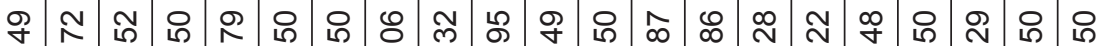

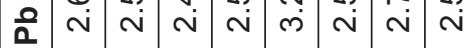

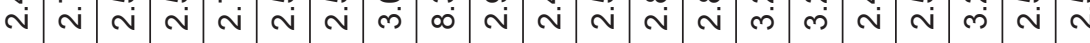


The results of analyzes have also shown a relation between the total lead content and its level in plants. The lead content in some plants (Table 2) did not correlate with a lead content in bioavailable forms (Table 1), which may be due to the fact that 73 to $95 \%$ of the metal compounds in plants is of atmospheric origin, not geochemical one from the soil (Kabata-Pendias and Pendias 2001-a).

Lead is one of the elements strongly accumulated in the plant. The observed high correlation coefficient between the lead and zinc in the exchangeable form in soil could suggest that in different plant organs one can also notice apparent positive correlation between these metals. However, in the literature (Aslan et al. 2003, Bolan et al. 2003) there is emphasized the presence of antagonism between metals and macro- or microelements, therefore, this issue is illustrated by a series of engravings, that show the changes to the quotient of the contents of $\mathrm{Pb} / \mathrm{Zn}$ in the tested plants as a function of $\mathrm{Zn}$ content changes Fig. 1-4.

In all the analyzed organs of the plants, together with the increase of zinc content there is observed the antagonism of lead, the content of which is maintained at the level characteristic for the species (Figs. 1-4). In the roots of the tested species, with the zinc content of 200 to $600 \mu \mathrm{g} / \mathrm{g}$, antagonism of lead is found in the following plants: St. John's wort (Hypericum hirsutum L.), Carthusian Pink (Dianthus carthusianorum L.), and Devil's-bit Scabious (Succisa pratensis Moench.) - Fig. 1.

Antagonism of lead in the stems of the tested plants due to large content of zinc (range 100-180 $\mu \mathrm{g} / \mathrm{g}$ ) refers to the species: cypress spurge (Euphorbia cyparissias L.), bush vetch (Vicia sepium L.), wild thyme (Thymus serpyllum L. emend. Fr.), Carline thistle (Carlina vulgaris L.), hairy St. John's wort (Hypericum hirsutum L.), hoary alyssum (Berteroa incana (L.) DC.), Heath Bedstraw (Galium saxatile L.), Woodland ragwort (Senecio sylvaticus L.) and Carthusian Pink (Dianthus carthusianorum L.) - Fig. 2.

When the zinc content is from 100 to $180 \mu \mathrm{g} / \mathrm{g}$, antagonism of lead is in flowers of the following plant species (Fig. 3): Marsh Ragwort (Senecio aquaticus Hill), Bladder campion (Silene vulgaris (Moench) Garcke), Creeping Yellowcress (Rorippa sylvestris (L.) Besser), Carthusian Pink (Dianthus carthusianorum L), Woodland Ragwort (Senecio sylvaticus L.) and wild thyme (Thymus serpyllum L. emend. Fr.).

Antagonism between lead and zinc were also observed in the leaves of individual plant species (Fig. 4). When zinc content is 300 to $800 \mu \mathrm{g} / \mathrm{g}$, antagonism of lead refers to the following species: Devil's-bit Scabious (Succisa pratensis Moench.), Cowbane (Cicuta virosa L.) and Woodland Ragwort (Senecio sylvaticus L.).

One of the important factors affecting the uptake of the metals from soil is a plant species and root structure. The literature widely describes the differences in the uptake and accumulation of metals depending on the element, plant species and population (Krzesłowska et al. 2010, Peralta-Videa et al. 2009, Korzeniowska and Stanisławska-Glubiak 2007, Vaillant et al. 2005, Tyksiński and Kurdubska 2004, Lehmann and Rebele 2004, Shu et al. 2002, Mengel et al. 2001, Kabata-Pendias and Pendias 2001-b, Marschner 1995). So far, there has also been proved that an adequate content of microelements can lead to a reduction in accumulation of heavy metals in plants (Gruca-Królikowska and Wacławek 2006). According to Kabata-Pendias, zinc impairs the transport of lead to the aerial parts of plants (Kabata-Pendias and Pendias 2001-a), which could confirm the observed phenomenon of discrimination of lead by zinc in the case of flowers, stems and leaves of some tested species.

In conclusion, the above analyses show that the potential antagonism between $\mathrm{Pb}$ and $\mathrm{Zn}$ occurs only in the case of some plants (and within the selected organs of the plants). Therefore, in order to illustrate better the degree and way of coexistence of the analyzed metals in different organs of the tested plants the linear regression equation was used (Figs. 5-8). The interpretation of the regression equations presented below is as follows: the coefficient before the metal is a measure of the increase (or decrease) of the contents of one element while changing the content of the other element; the intercept is the value above which one can observe a certain relation, which is described by the correlation coefficient.

The change of $\mathrm{Pb}$ content in the function of $\mathrm{Zn}$ content changes in roots of the tested plant species is described by regression equation (Fig. 5): $\mathrm{Pb}=0,0143 * \mathrm{Zn}+5,26$; $\mathrm{R}^{2}=0,0485$. According to the above interpretation, the change in $\mathrm{Zn}$ content by 100 units will result in the increase of $\mathrm{Pb}$ in the root by $1.43 \mu \mathrm{g}$, but only above the level of $\mathrm{Zn}$ equal to 5.26. The above conclusion is justified for $4.85 \%$ of the cases. Analysing the equation describing the change of $\mathrm{Pb}$ and $\mathrm{Zn}$ in stems of the tested plants (Fig. 6).: $\mathrm{Pb}=0.0037^{*} \mathrm{Zn}+2.78$; $\mathrm{R}^{2}=0.018$, we note that the change in $\mathrm{Zn}$ content by 100 units causes an increase of $\mathrm{Pb}$ content in the stems by $0.9 \mu \mathrm{g}$ (when the $\mathrm{Zn}$ content is higher than 2.61). This relation describes less than $2 \%$ of cases. Considering the next two regression equations describing the change of $\mathrm{Pb}$ and $\mathrm{Zn}$ content in flowers (Fig. 7.) and leaves (Fig. 8.) we can see that they describe a number of cases which are insignificant from the statistical point of view: flowers: $\mathrm{Pb}=-6 \mathrm{E}-05^{*} \mathrm{Zn}+2.95 ; \mathrm{R}^{2}=5 \mathrm{E}-06$; leaves: $\mathrm{Pb}=0.0038^{*} \mathrm{Zn}+3.37 ; \mathrm{R}^{2}=0.047$.

The calculated Pearson correlation coefficients (root: 0.220; stalk: 0.134; flower: -0.002; leaf: 0.217) indicate a low level of relation between the considered variables. The considerations therefore confirm that the competition between $\mathrm{Pb}$ and $\mathrm{Zn}$ is not a permanent phenomenon, but is likely to be observed in some morphological parts of the selected plant species. Confrontations of intercepts including the regression equations for the root, stem, flowers and leaves are considered helpful in explaining physiological levels of a given element and the various interactions between metals.

The above considerations are confirmed by Aery and Rana (Aery and Rana 2007), who while studying the interactions between $\mathrm{Zn}$ and $\mathrm{Pb}$ in barley also observed antagonistic reactions between these metals, but only at a specific (in this case higher), range of concentrations of these metals. A similar relation has been noted by Symeonidis and Karataglis (Symeonidis and Karataglis 1992) in the studies of interactions between the metals in Holcus lanatus $\mathrm{L}$. The antagonistic effect of $\mathrm{Zn}$ on $\mathrm{Pb}$ was also observed in Faba vulgaris Moench (Bystrická et al. 2013). Reduction of lead content to $0.61 \pm 0.17 \mu \mathrm{g} / \mathrm{g}$ was due to the presence of zinc in an amount of $80 \mu \mathrm{g} / \mathrm{g}$. According to the authors of the cited works (Khan et al. 2013), the response of plants in such a situation is sometimes individual, and the decrease in lead content in the presence of zinc (with a different range of concentrations of these metals), should be treated as a feature specific to a given species. 


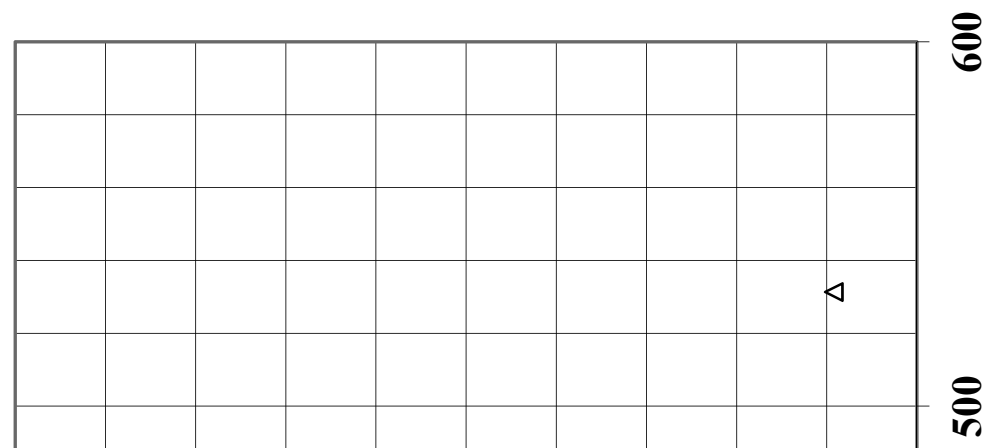

छ)
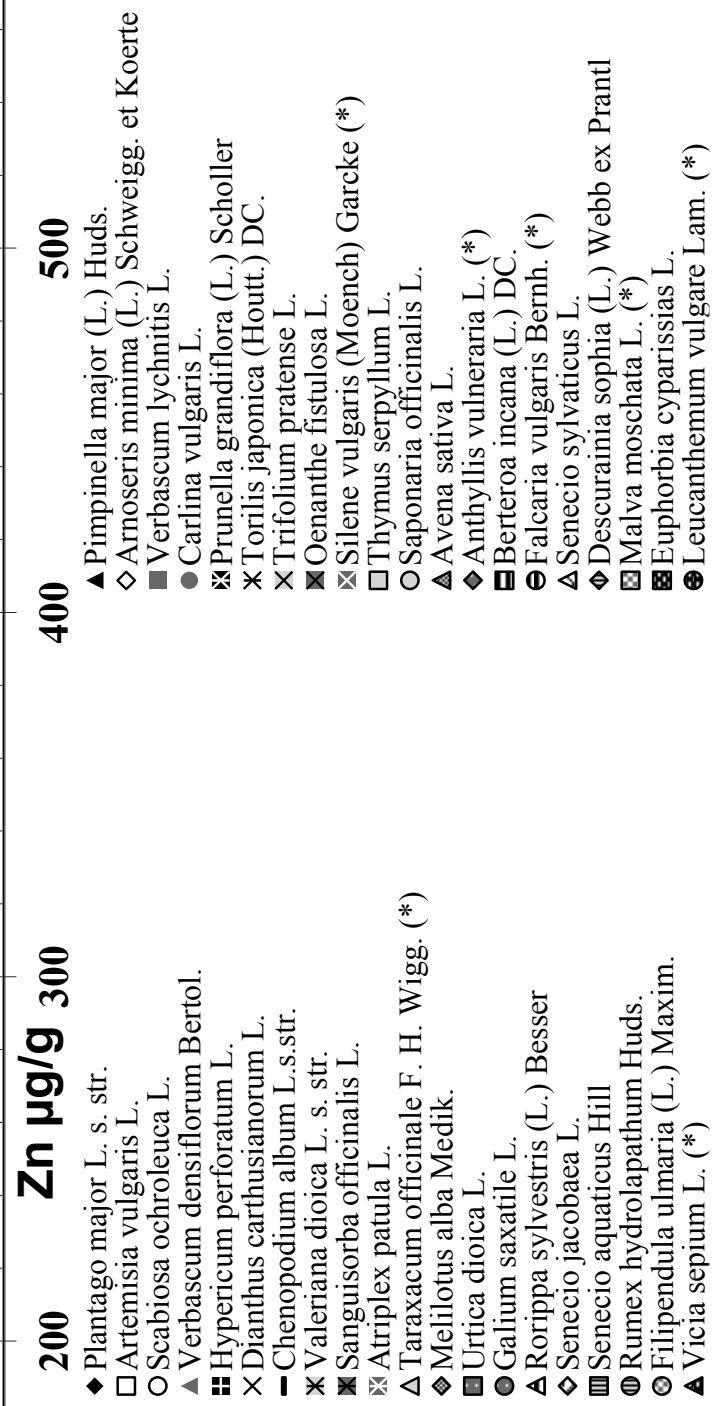

8

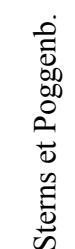

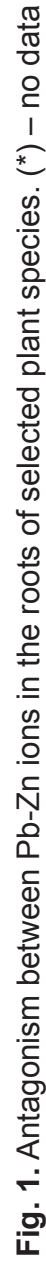

$-$

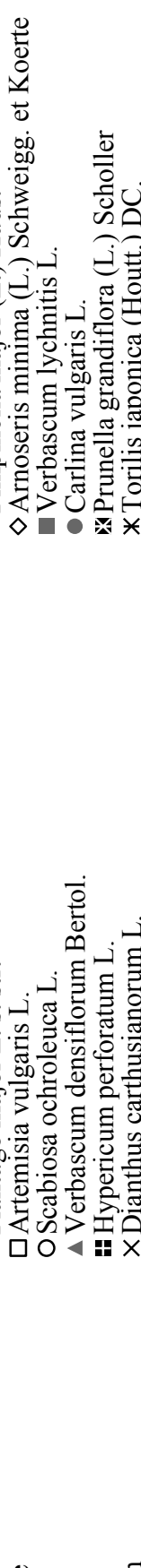
四

$\diamond \mid$\begin{tabular}{l|l|l|}
\hline 血 & \\
\hline
\end{tabular}

而

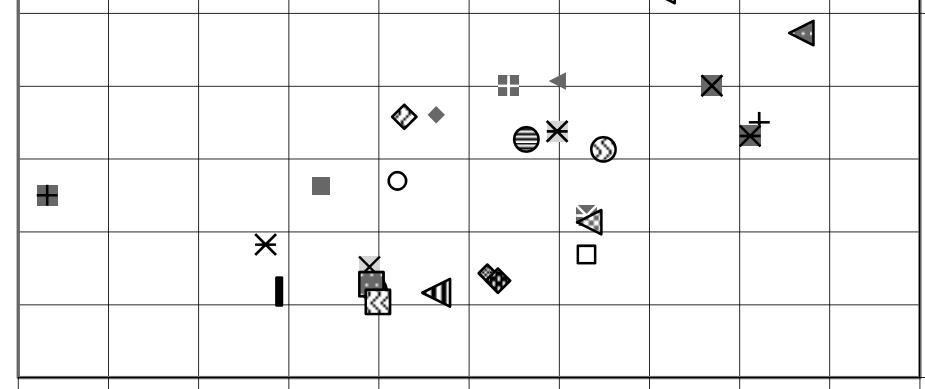

0

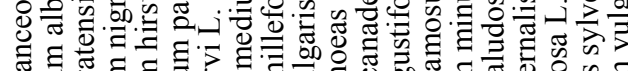

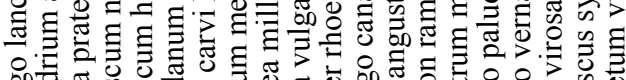




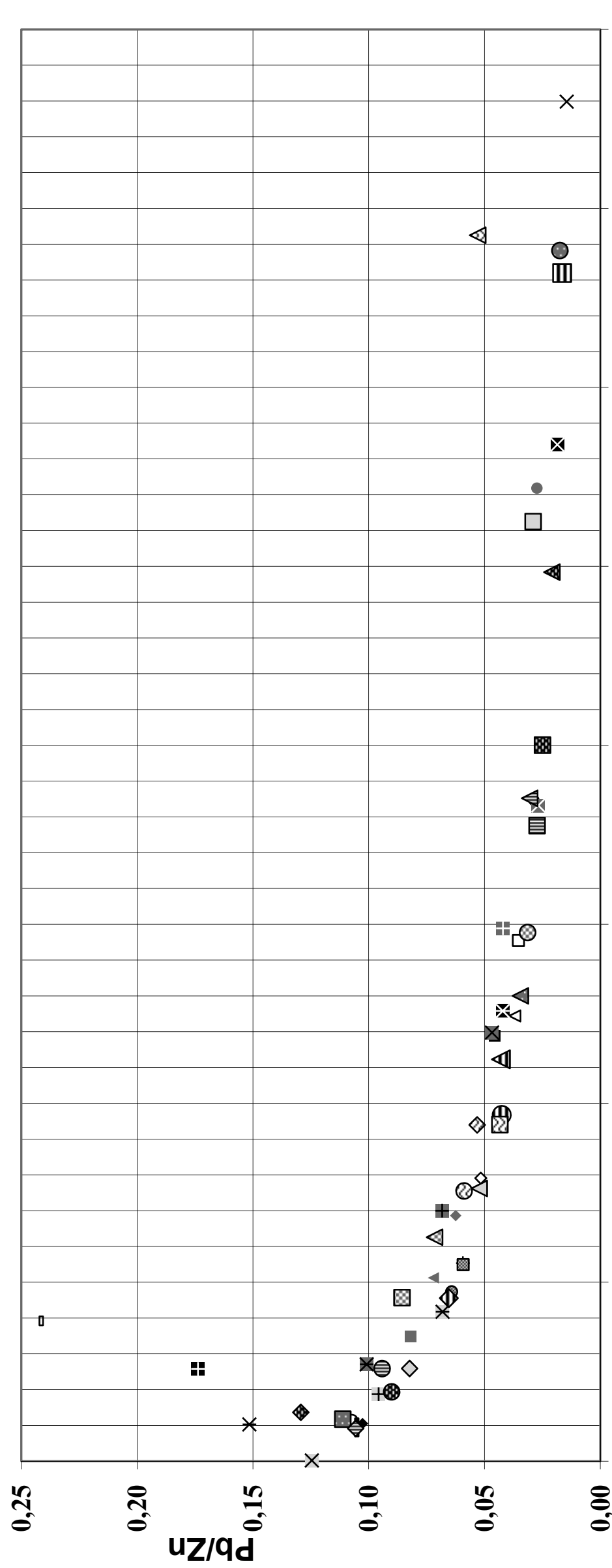

$\stackrel{\infty}{\stackrel{0}{\infty}}$

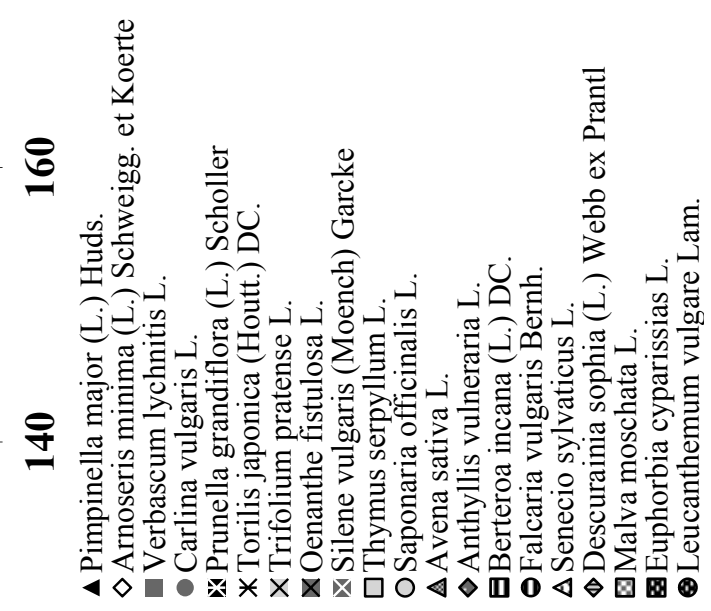

తิ

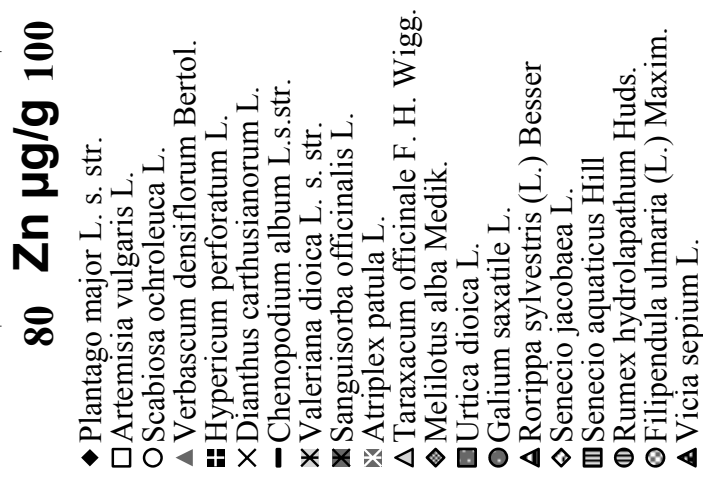

8

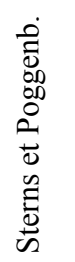

¿'

$\frac{E^{\infty}}{\omega}$

$\stackrel{9}{\rightleftharpoons}$

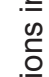

N

$\frac{\dot{0}}{0}$

离

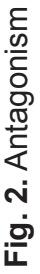

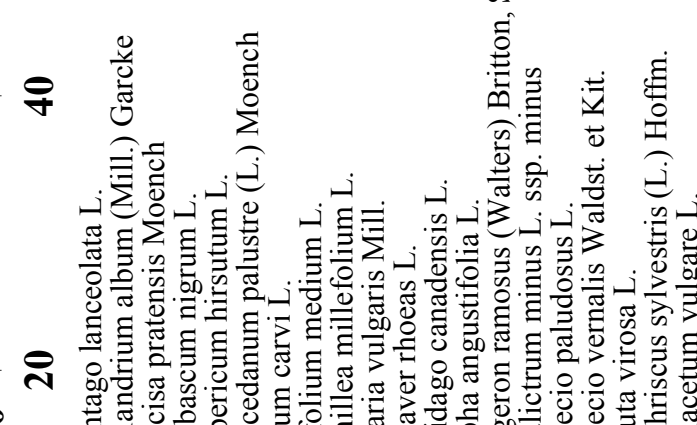

8 


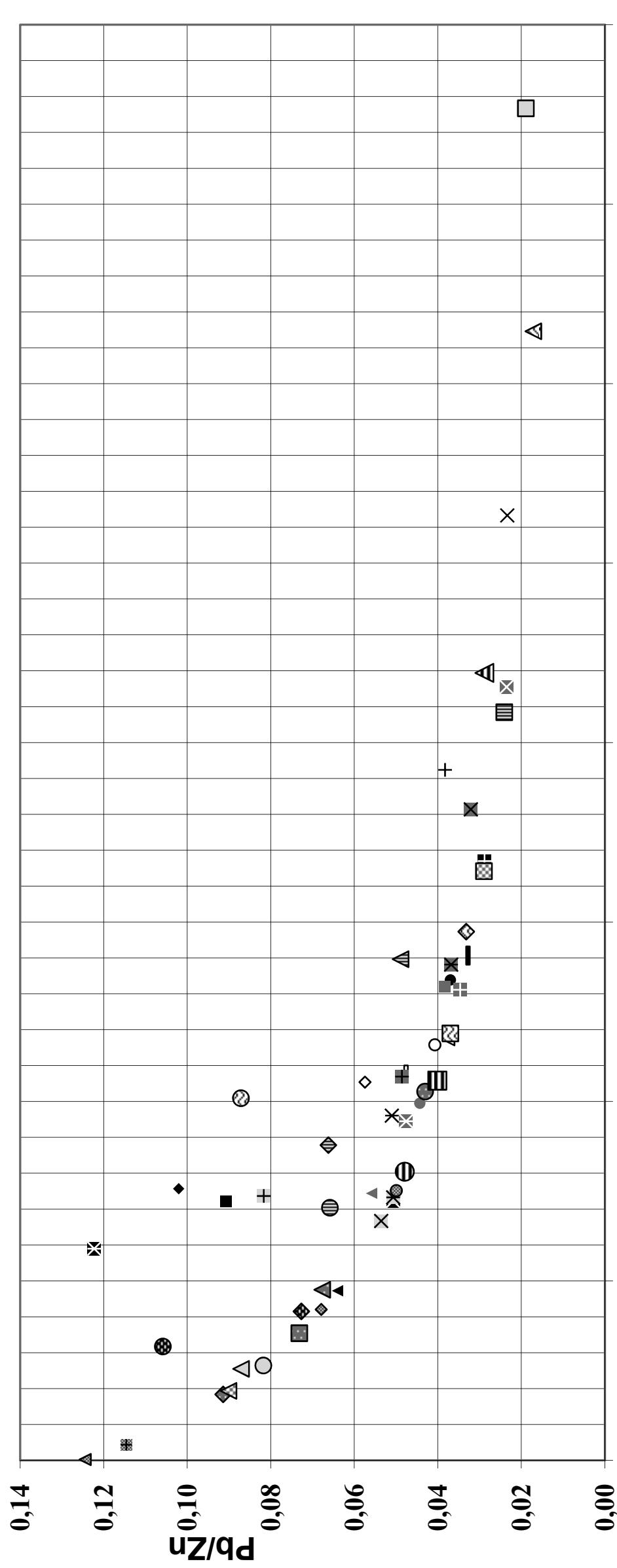

$\stackrel{\infty}{-}$

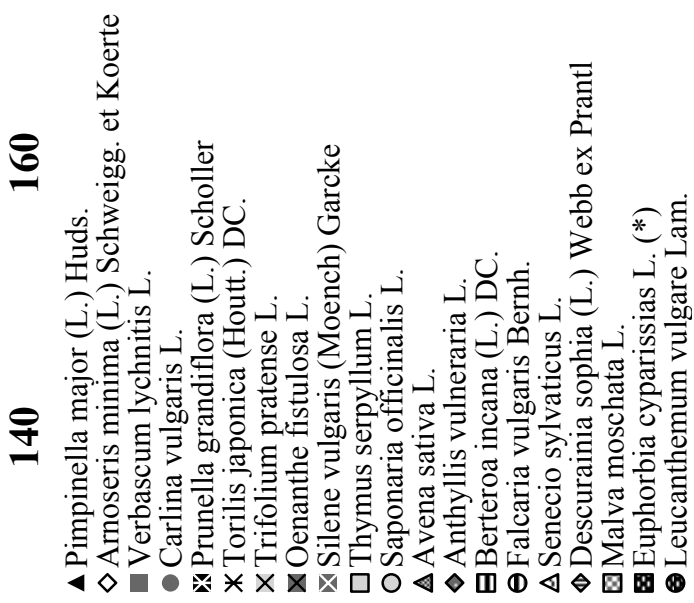

తิ

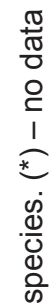

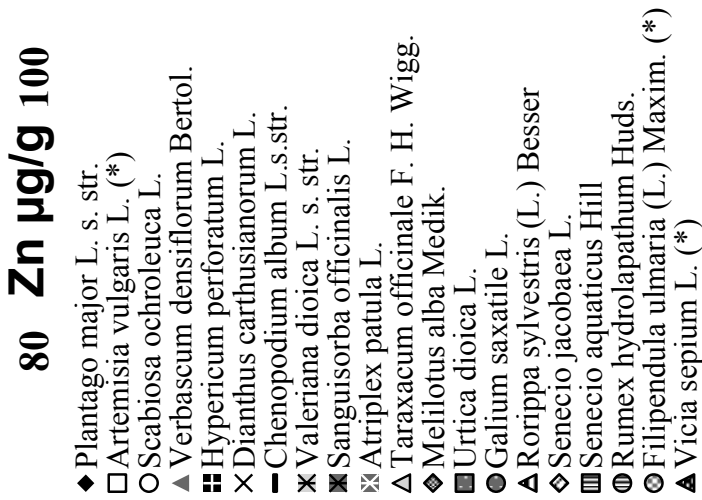

8

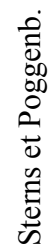

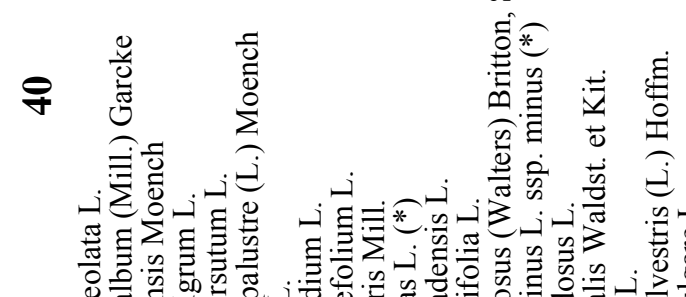

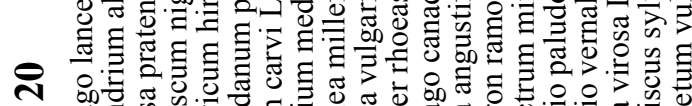

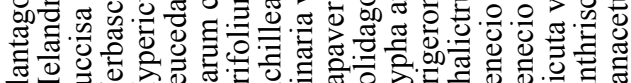

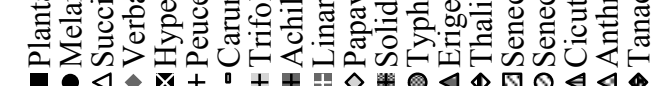




\begin{tabular}{|l|l|l|l|l|l|l|l|}
\hline & & & & & & & \\
\hline & & & & & & & \\
\hline & & & & & & & 4 \\
\hline & & & & & & & \\
\hline & & & & & & & \\
\hline & & & & & & & \\
\hline
\end{tabular}

ஓి

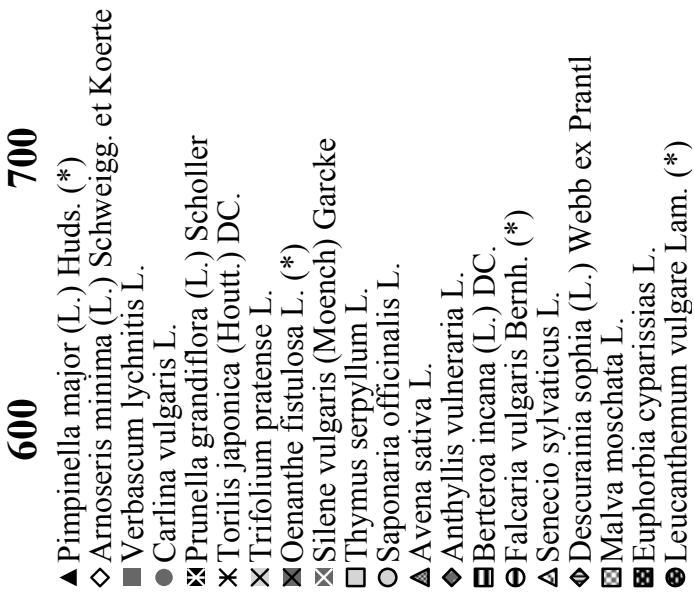

응

4

\begin{tabular}{|l|l|l|l|l|l|l|}
\hline & & & & & & \\
\hline
\end{tabular}

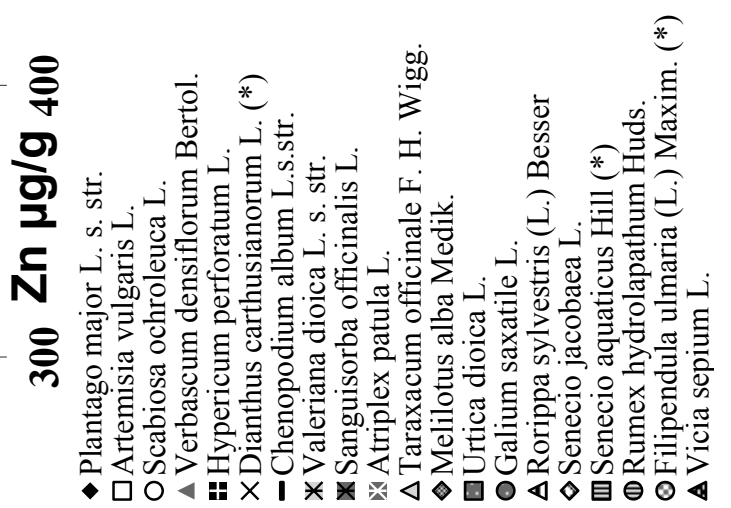

$\triangleleft$

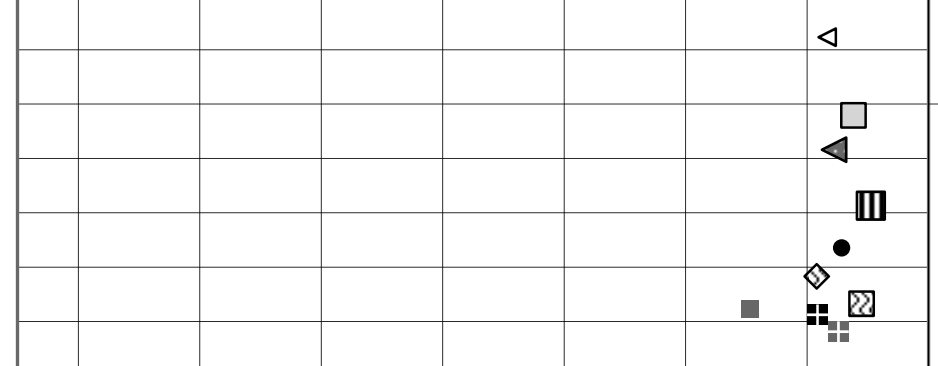

ชี่

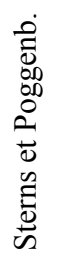

-

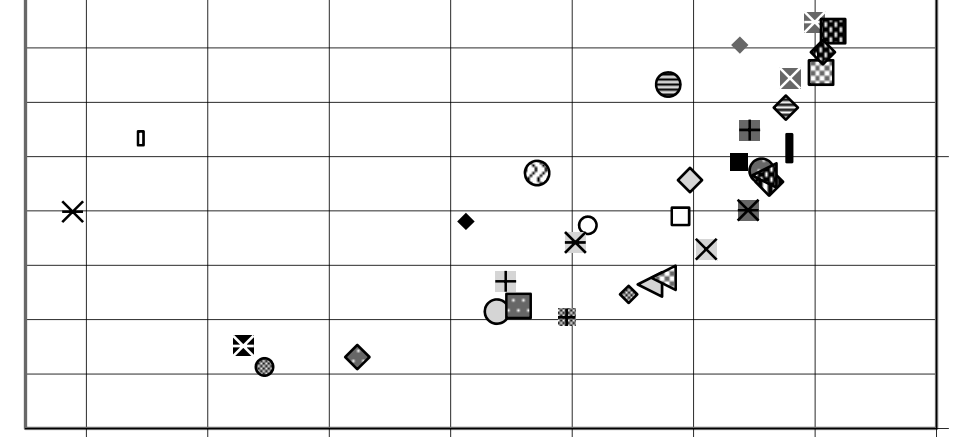

ఠ

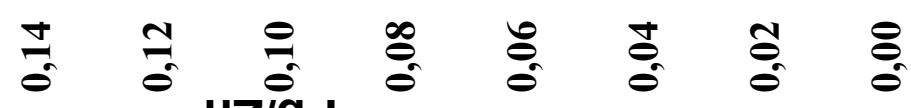

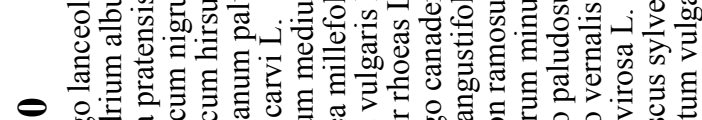

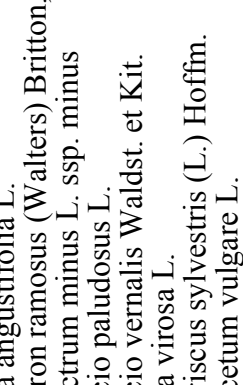

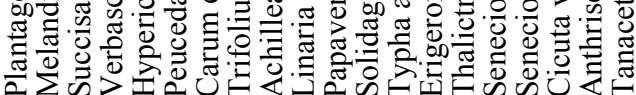
uz/9d 


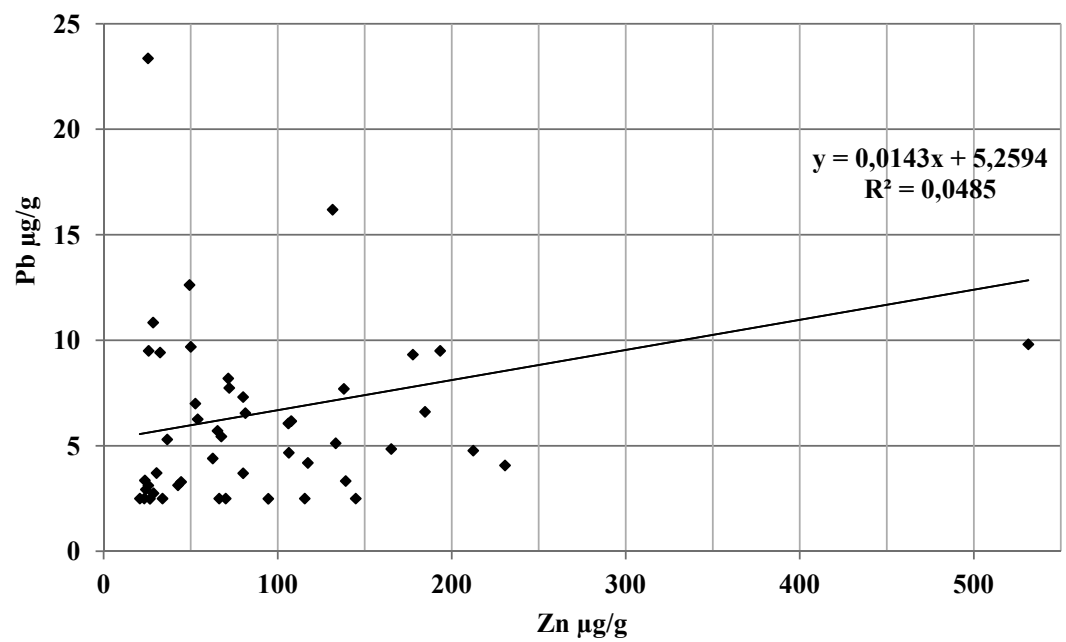

- ROOTS

Fig. 5. Simple linear regression equation showing the relationships between $\mathrm{Pb}$ and $\mathrm{Zn}$ in roots $(\mathrm{n}=49)$

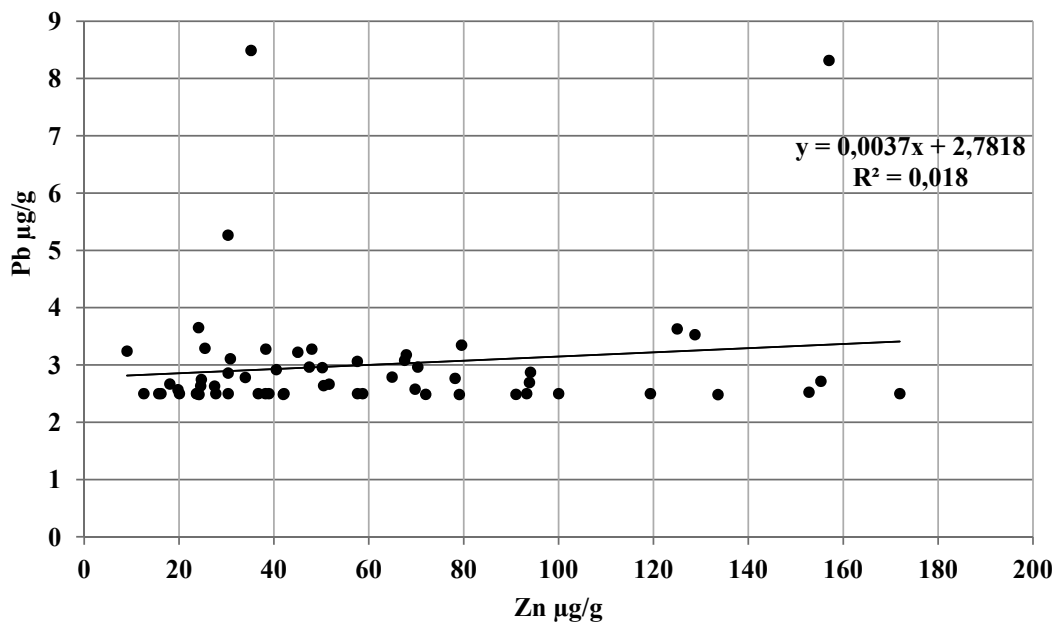

- STEMS

Fig. 6. Simple linear regression equation showing the relationships between $\mathrm{Pb}$ and $\mathrm{Zn}$ in stems $(\mathrm{n}=60)$

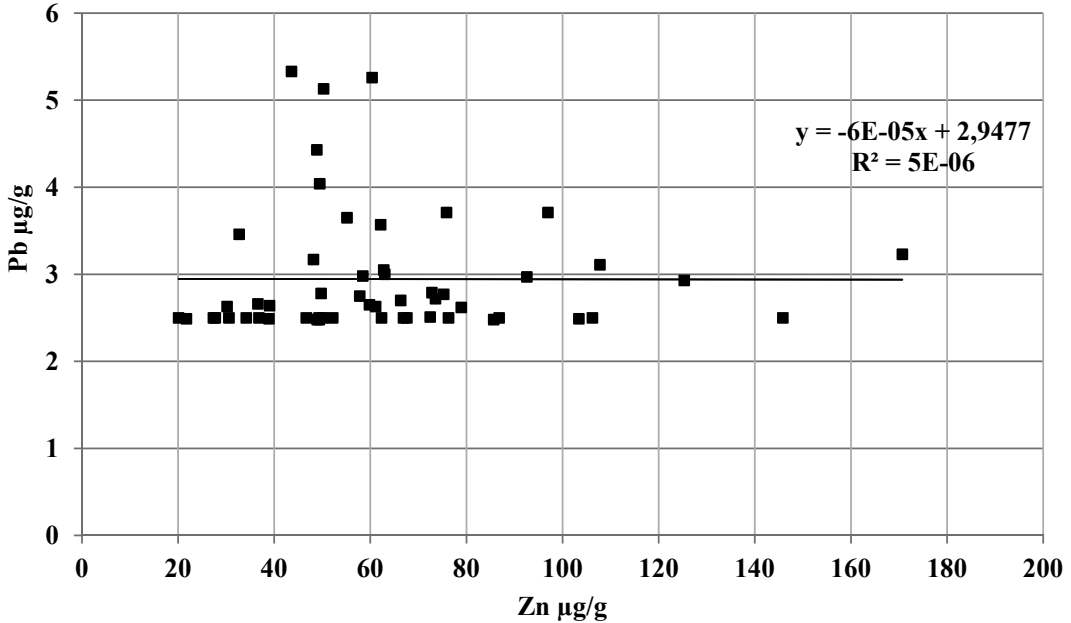

- FLOWERS

Fig. 7. Simple linear regression equation showing the relationships between $\mathrm{Pb}$ and $\mathrm{Zn}$ in flowers $(\mathrm{n}=54)$ 


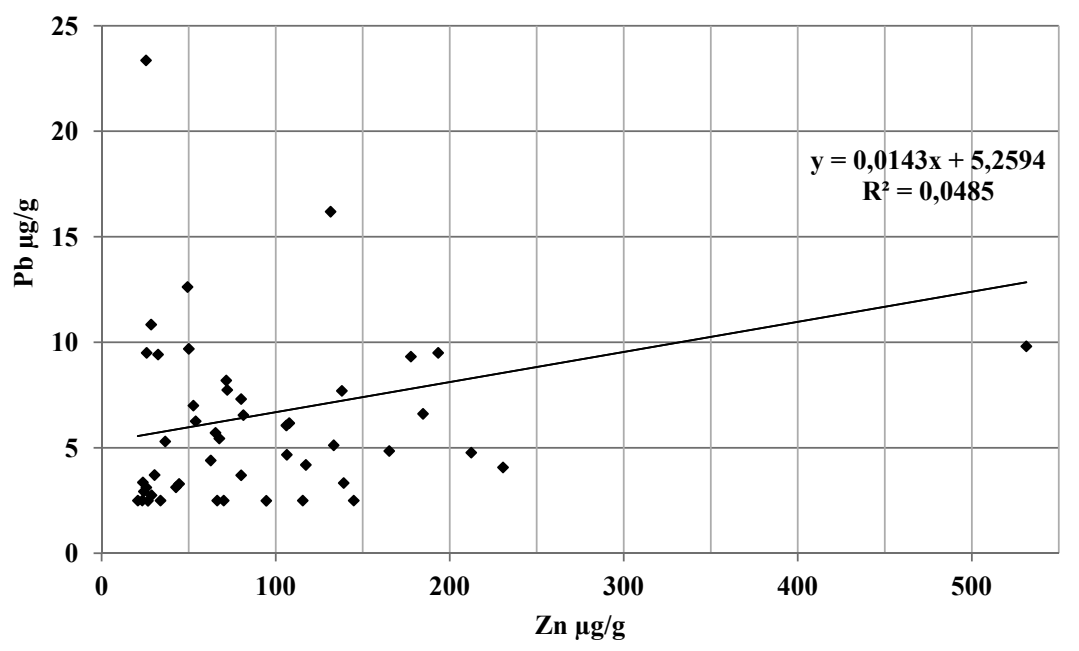

- ROOTS

Fig. 8. Simple linear regression equation showing the relationships between $\mathrm{Pb}$ and $\mathrm{Zn}$ in leaves $(\mathrm{n}=52)$

\section{Conclusions}

1. Antagonism between lead and zinc occurs in all organs of most investigated plant species (60).

2. It was confirmed that the antagonism between lead and zinc in plants occurs in some range of concentrations of the metals, characteristic for a given species.

3. The so-called $\mathrm{Zn}$ limits above which the antagonism of lead occurs were determined for each plant species.

4. The on-going observations show that Carthusian Pink (Dianthus carthusianorum L.), wild thyme (Thymus serpyllum L.emend. Fr.), Woodland Ragwort (Senecio sylvaticus L.), Devil's-bit Scabious (Succisa pratensis Moench.) and hairy St John's wort (Hypericum hirsutum L.) are the species in which the strongest antagonism between lead and zinc occurs.

\section{References}

Aery, N.C. \& Rana, D.K. (2007). Interactive effects of $\mathrm{Zn}, \mathrm{Pb}$ and $\mathrm{Cd}$ in barley, Journal of Environmental Engineering and Science, 49, 1, pp. 71-76.

Aslan, M., Ünlü, M.Y., Türkmen, N. \& Yilmaz, Y.Z. (2003). Sorption of cadmium and effects on growth, protein content and photosynthetic pigment composition of Nasturtium officinale R. Br. and Mentha aquatic L., Bulletin of Environmental Contamination and Toxicology, 71, pp. 323-329.

Badora, A. \& Kozłowska-Strawska, J. (2011). Some quality indicators of arable plants, Ochrona Środowiska i Zasobów Naturalnych, 48, pp. 439-452. (in Polish)

Bednarek, R., Dziadowiec, H., Pokojska, U. \& Prusinkiewicz, Z. (2005). Ecological and pedological research, Wydawnictwo Naukowe PWN, Warszawa 2005. (in Polish)

Bolan, N.S., Adriano, D.C., Mani, P.A. \& Duraisamy, A. (2003). Immobilization and phytoavailability; toxicity of cadmium in variable charge soils. II. Effect of lime addition, Plant Soil, 25, pp. 187-198.

Bystrická, J., Tomáš, J., Tóth, T., Trebichalský, P. \& Kavalcová, P. (2013). Potential antagonist $\mathrm{Zn}$ effect on faba bean (Faba vulgaris m.), Environmental Protection And Natural Resources, 24, 2, 56, pp. 21-24.

Czarnowska, K. (1996). Total contents of heavy metals in luvisols of the Siedlce Plateau, Zeszyty Naukowe $S G G W-A R$ Warszawa, Rolnictwo, 16, pp. 39-47. (in Polish).
Dziubanek, G., Baranowska, R. \& Oleksiuk, K. (2012). Heavy metals in the soils of Upper Silesia - a problem from the past or a present hazard? Journal of Ecology and Health, 16, 4, pp. 169-176. (In Polish)

Eapen, S. \& D'souza, S.F. (2005). Prospect of genetic engineering of plants for phytoremediation of toxic metals, Biotechnology Advances, 23, pp. 97-114.

Furmanek, T. \& Andrzejewska-Ponomarev, M. (2006). The effects of lead on growing tomato plants Lycopersi-con Sp. determined in in vitro cultures, Stupskie Prace Biologiczne 3, pp. 5-12. (in Polish)

Gruca-Królikowska, S. \& Wacławek, W. (2006). Metals in the environment. Vol. II Effect of heavy metals on plants, Chemia. Dydaktyka. Ekologia. Metrologia. 11, 1-2, pp. 41-46. (in Polish)

Hereźniak, J. (1984). Documentation of the proposed the Prof. Wladyslaw Hyla forest reserve Gaszczyk in Czestochowa, Łódź 1984. (in Polish)

Hławiczka, S. (2008). Heavy metals in the environment, PIETU, Wydawnictwo Ekonomia i Środowisko, Białystok 2008. (in Polish)

Jadia, C.D. \& Fulekar, M.H. (2009). Phytoremediation of heavy metals: Recent techniques, African Journal of Biotechnology, 8, pp. 921-928.

Janowska, B. \& Szymański, K. (2005). Immobilization of heavy metals in aquatic and terrestrial environment subjected to anthropogenic pressure, in: VII National Conference on: Comprehensive and detailed problems of the environment engineering, T. Piecuch (Ed.), Wyd. Politechniki Koszalińskiej, Koszalin 2005. (in Polish)

Jin, C.W., Zheng, S.J., He, Y.F., Zhou, G.D. \& Zhou, Z.X. (2005). Lead contamination in tea garden soils and factors affecting its bioavailability, Chemosphere, 59, pp. 1151-1159.

Kabata-Pendias, A. \& Mukherjee, A.B. (2007). Trace elements from soil to human, Springer-Verlag, Berlin-Heidelberg 2007.

Kabata-Pendias, A. \& Pendias, H. (2001-a). Biogeochemistry of trace elements, Wydawnictwo Naukowe PWN, Warszawa 2001. (in Polish)

Kabata-Pendias, A. \& Pendias, H. (2001-b). Trace elements in soils and plants, CRC Press LLC, Boca Raton, Florida, USA 2001.

Karczewska, A. Spiak, Z. Kabała, C. Gałka, B. Szopka, K. Jezierski, P. \& Kocan, K. (2008). Evaluation of the use of supported phytoextraction in the remediation of soils contaminated by copper smelter emissions, Wydawnictwo Zante, Wrocław 2008. (in Polish) 
Khan, S., Naz, A., Asim, M., Ahmad, S.S., Yousaf, S. \& Muhammad, S. (2013). Toxicity and bioaccumulation of heavy metals in spinach seedlings grown on freshly contaminated soil, Pakistan Journal of Botany, 45, S1, pp. 501-508.

Korzeniowska, J. \& Stanisławska-Glubiak, E. (2007). Reactions of three varieties of mustard to contamination with copper, zinc and nickel, Ochrona Środowiska i Zasobów Naturalnych, 32, pp. 87-93. (in Polish)

Krzesłowska, M., Samardakiewicz, S. \& Woźny, A. (2010). Trace metals in: The reactions of plant cells to stress factors. Volume 2, Woźny A. \& Goździcka-Józefiak, A. (Ed.). Wyd. Nauk. Uniwersytetu w Poznaniu, Poznań 2010, pp. 90-146. (in Polish)

Krzywy, I., Krzywy, E., Pastuszak-Gabinowska, M. \& Brodkiewicz, A. (2010). Lead- is there something to be afraid of? Annales Academiae Medicae Stetinensis, 56, 2, pp. 118-128. (in Polish)

Kwiatkowska-Malina, J. \& Maciejewska, A. (2011). The uptake of heavy metals by plants at differentiated soil reaction and content of organic matter, Ochrona Środowiska i Zasobów Naturalnych, 49, pp. 43-51. (in Polish)

Lehmann, C. \& Rebele, F. (2004). Evaluation of heavy metal tolerance in Calamagrostis epigeios and Elymus repens revealed copper tolerance in a copper smelter population of C. epigeios, Environmental and Experimental Botany, 51, pp. 199-213.

Marschner, H. (1995). Mineral nutrition of higher plants, Academic Press Ltd., London, Great Britain 1995.

Mengel, K., Kirkby, E.A., Kosegarten, H. \& Appel, T. (2001). Principles of plant nutrition, Kluwer Acad. Publ., The Netherlands 2001.

Musielińska, R., Kowol, J., Kwapuliński, J., Rochel, R. \& Oleś, U. (2014). Discrimination of lead in plants by calcium and magnesium, Ekologia i Technika, 22, 3, pp. 106-110. (in Polish)

Nagajyoti, P.C., Lee, K.D. \& Sreekanth, T.V.M. (2010). Heavy metals, occurrence and toxicity for plants: a review, Environmental Chemistry Letters, 8, pp. 199-216.

Niesiobędzka, K. (2000). The bioavailability forms of heavy metals in soils, Ecological Chemistry and Engineering, 7, 5, pp. 521-530. (in Polish)

Niesiobędzka, K., Wojtkowska, M. \& Krajewska, E. (2005). Migration of zinc, lead and cadmium in the system soil - vegetation in the urban environment, IOŚ, Warszawa 2005. (in Polish)

Ociepa, A., Pruszek, K., Lach, J. \& Ociepa, E. (2008). Effect of long-term soil fertilization with manure and sewage sludge on the increase in the content of heavy metals in soils, Ecological Chemistry and Engineering S, 1, 15, pp. 103-109. (In Polish)

Ociepa-Kubicka, A. \& Ociepa, E. (2012). Toxic effects of heavy metals on plants, animals, humans, Inżynieria i Ochrona Środowiska, 15, 2, pp. 169-180. (in Polish)

Peralta-Videa, J.R., Lopez, M.L., Narayan, M., Saupe, G. \& GardeaTorresdey, J. (2009). The biochemistry of environmental heavy metal uptake by plants: Implications for the food chain, The International Journal of Biochemistry \& Cell Biology, 41, pp. 1665-1677.

Rao, M.K.K. (2006). Physiology and molecular biology of stress tolerance in plants, Springer, Netherlands 2006.

Regulation of the Minister of Environment on soil quality standards and ground quality standards, Dz. U. no 165/2002 pos. 1359. (in Polish)

Rout, G.R. \& Das, P. (2003). Effect of metal toxicity on plant growth and metabolism: I. Zinc, Agronomie, 23, 1, pp. 3-11.

Rudd, T., Lake, D.L., Mehrotra, I., Sterritt, R.M., Kirk, P.W.W., Campbell, J.A. \& Lester, J.N. (1988). Characterisation of metal forms in sewage sludge by chemical extraction and progressive acidification, Science of the Total Environment, 74, pp. 149-175.

Sady, W. (2001). Factors limiting the content of nitrates and heavy metals in vegetables, Przemyst Fermentacyjny $i$ Owocowo-Warzywny, 5, pp. 21-23. (in Polish)

Sas-Nowosielska, A. (2009). Phytotechnologies in the remediation of contaminated sites by zinc-lead industry, Monograph No. 189, Wyd. Politechniki Częstochowskiej, Częstochowa 2009. (in Polish)

Sauve S. McBride M.B. Norvell W.A. Hendershot W.H. (1997). Copper solubility and speciation of in situ contaminated soils as effects of copper level, $\mathrm{pH}$ and organic matter, Water, Air Soil Pollut., 100, pp. 133-149.

Shu, W.S., Ye, Z.S., Zhang, Z.Q. \& Wong, M.H. (2002). Lead, zinc and copper accumulation and tolerance in populations of Paspalum distichum and Cynodum dactylon, Environmental Pollution, 120, pp. 455-453.

Siwek, M. (2008). Plants in contaminated with heavy metals industrial environment. Part I. Uptake, transport and toxicity of heavy metals (trace), Wiadomości Botaniczne, 52, 1/2, pp. 7-22. (in Polish)

Skołożdrzy, J., Perła, J., Smól, J. \& Twardowski, T. (2001). Heavy metals: iron, lead and cadmium - a threat to the plants only? Ochrona Roślin, 5, 6, pp. 2-6. (in Polish)

Suna, Y., Zhou, Q., Xie, X. \& Liu, R. (2010). Spatial, sources and risk assessment of heavy metal contamination of urban soils in typical regions of Shenyang, China, Journal of Hazardous Materials, 174, pp. 455-462.

Symeonidis, L. \& Karataglis, S. (1992). Interactive effects of cadmium, lead and zinc on root growth of two metal tolerant genotypes of Holcus lanatus L., Biometals, 5, 3, pp. 173-178.

Terelak, H., Motowicka-Terelak, T., Stuczyński, T. \& Pietruch, C. (2000). Trace elements (Cd, Cu, Ni, Pb, Zn) in soils of Polish farmland, IOŚ, Warszawa 2000. (in Polish)

Tyksiński, W. \& Kurdubska, J. (2004). Varietal differences in the accumulation of cadmium and lead by radish (Raphanus sativus L.), Rocznik Akademii Rolniczej w Poznaniu, 356, pp. 209-215. (in Polish)

Usman, A.R.A., Kuzyakov, Y., Lorenz, K. \& Stahr, K. (2006). Remediation of a soil contaminated with heavy metals by immobilizing compounds, Journal of Plant Nutrition and Soil Science, 169, pp. 205-212.

Vaillant, N., Monnet, F., Hitmi, A., Sallonon, H. \& Cou-Dret, A. (2005). Comparative study of responses in four Datura species to a zinc stress, Chemosphere, 59, pp. 1005-1013.

Wacławek, W. \& Maćko, A. (2001). Relationships between soil properties and speciation forms of heavy metals, Chemia i Inżynieria Środowiska, 8, 2-3, pp. 253-268. (in Polish)

Whiteside, P.J. \& Milner, A. (1984). Pye Unicam Atomic Absorption Data Book, Pye Unicam Ltd, 1984.

Woźny, A. (1995). Lead in plant cells: uptake, reactions, resistance, Wydawnictwo Sorus, Poznań 1995. (in Polish)

Wybieralski, J. \& Maciejewska, M. (2011). Research on the level of heavy metal contamination of soil and plants in the border areas in Rosołówek near Szczecin, Chemia i inżynieria ekologiczna, 8, 7, pp. 741-748. (in Polish)

Zwonitzer, J.C., Pierzynski, G.M. \& Hettiarachchi, G.M. (2003). Effects of phosphorus addition on lead, cadmium, and zinc bioavailabilities in a metal-contaminated soil, Water, Air \& Soil Pollution, 143, pp. 193-209. 


\section{Antagonizm pomiędzy jonami ołowiu i cynku w roślinach}

Streszczenie: $\mathrm{W}$ artykule przedstawiono wyniki badań opisujące występowanie antagonizmu pomiędzy $\mathrm{Pb}-\mathrm{Zn}$ w wybranych gatunkach roślin z terenu Częstochowy - dzielnica Mirów (północno-zachodnia część Wyżyny Częstochowskiej). Analizowano zmiany ilorazu zawartości $\mathrm{Pb} / \mathrm{Zn}$ w poszczególnych organach badanych roślin jako funkcję zmian zawartości Zn. Zawartość metali w roślinach i w glebie została określona metodą atomowej spektrofotometrii absorpcyjnej AAS. We wszystkich organach roślin obserwowano antagonistyczny spadek pobierania i kumulacji $\mathrm{Pb}$, będący skutkiem wzrostu koncentracji $\mathrm{Zn}$.

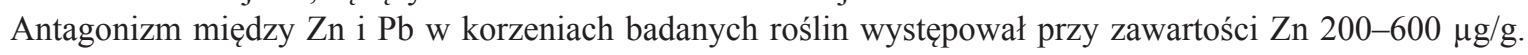
Z kolei w łodygach i w kwiatach, antagonizm występował przy niższych zawartościach cynku (100-180 $\mu \mathrm{g} / \mathrm{g})$. $\mathrm{W}$ liściach antagonizm pomiędzy $\mathrm{Pb}$ i $\mathrm{Zn}$ pojawiał się w przypadku obecności $\mathrm{Zn}$ na poziomie zawartości $300-800 \mu \mathrm{g} / \mathrm{g}$.

Szczegółowe wyniki analiz potwierdzają obecność antagonizmu ołowiu w niektórych roślinach, w odniesieniu do dużych zawartości cynku. Badania potwierdziły także, że stopnień antagonizmu zależy od gatunku rośliny. 